\title{
外科的矯正治療における顎位の決定 \\ Condylar positioning of orthognatic surgery
}

冨永 和宏

Kazuhiro Tominaga

九州歯科大学 生体機能学講座 顎顔面外科学分野

Department of Science of Physical Function, Division of Maxillofacial Surgery,

Kyushu Dental University

齋 藤 功

Isao Saito

新潟大学大学院医歯学総合研究科歯科矯正学分野

Division of Orthodontics, Department of Oral Biological Science Niigata University

Graduate School of Medical and Dental Sciences

外科的矯正治療の目的は, 顎矯正手術を併用して咬合機能の回復と顔面の審美性の調和を図ること であり，治療結果は長期にわたって安定していることが必要である。それらの要件を満たすために は，形態的，機能的側面から現症を詳細に把握し，適切な分析・診断に基づいて最終ゴールをシミュ レーションしながら治療を進めることが必要で, 手術においてはそのシミュレーションされた結果を 正確に術野で再現し，ゴールを達成することが要求される。ゴールの達成と治療後の安定性にかかわ る重要な要因の一つに顎位の設定がある。顎位（jaw position）という言葉は下顎位として下顎の位 置を示すことが多いが，頭蓋に対して顎顔面骨を自由自在に動かせる顎矯正手術においては，下顎や 顎関節の位置だけでなく，頭蓋に対する顎顔面骨複合体の位置という広い意味を持つと考えられる。 そこで今回は，そのような広義の顎位設定について考えてみることとした。

かつては「これが予測や治療の限界」と言えば許容されていた時代もあったが，国民の顎変形症治 療に対する認知度と期待值の上昇により，治療ゴールをより高く設定する場合も多くなってきた。以 前のシミュレーションは 2 次元的なセファロ分析を中心に行われていたが，より精緻な治療を行うた めには 3 次元的な分析やシミュレーションが必須になりつつある。

今回のシンポジウムではそのような 3 次元的分析やシミュレーションを積極的に取り入れている矯 正歯科と口腔外科の先生方から，顎位の決定に配慮した診断と治療方針立案の概要，その具体的手 法，ならびに術後変化を含めた顎位設定のあり方を述べていただくこととした。 


\section{䫟矯正手術の最適なゴール設定とそれを実現するため の歯科矯正治療 \\ Establishment of optimal goals for orthognathic sur- gery and orthodontic treatment for their realization}

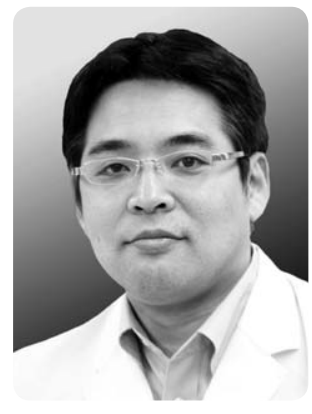

上地 潤 Jun Uechi

北海道医療大学歯学部歯学科

口腔構造・機能発育学系 歯科矯正学分野

Division of Orthodontics and Dentofacial Orthopedics,

Department of Oral Growth and Development, School of Dentistry,

Health Sciences University of Hokkaido

外科的矯正治療の要否を的確に判断し，最適な治療のゴールを設定するためには，脳頭蓋上顎複合 体と下顎骨を，骨格を構成する要素と歯・歯槽を構成する要素に分けて考える必要があります。脳頭 蓋，上顎骨，下顎骨，上顎歯列，下顎歯列の 5 要素について，(1)脳頭蓋と上顎骨，(2)脳頭蓋と下顎 骨, (3)上顎骨と下顎骨の 3 組の相対的位置関係を改変するのは, 顎矯正手術であり, (4)上顎骨と上顎 歯列，(5)下顎骨と下顎歯列の 2 組の相対的位置関係を改変するのは，矯正的歯の移動または歯・歯槽 部の手術であります。また， (6)上顎歯列と下顎歯列の相対的位置関係は、(1)から(5)改変の結果とし て得られる咬合関係となります。したがって，この 6 組の関係は個々の患者を形態学的に診断するう えで評価されなければならない主要な項目であり, 口腔外科医と矯正医は, 要素間の最適な相対的位 置関係を究明し，その実現可能性を詳細に検討して治療のゴールを設定する必要があります。

本院では、これまでコンピュータ支援診断・治療計画立案・手術システムの開発を行ってきまし た。本システムの特長の一つに, 術前矯正を終了した患者の三次元データから仮想患者モデルを生成 し，手術シミュレーションを施行することにより，顎矯正手術のゴールを精緻に設定・選択できる点 が挙げられます。具体的には，最初に下顎の骨切り術をシミュレートし，必要に応じて上顎骨やオト ガイ部，下顎下縁に骨切り術を追加することで，最適な手術法を推定することが可能となりました。

しかし，三次元的に複雑な変形をきたした顔面非対称症例では，いかなる付加的手術を追加しよう とも顔面の対称性が獲得できないと予想される症例にしばしば遭遇します。このような症例を詳細に 分析したところ，(5)下顎骨と下顎歯列の相対的位置関係に不調和が存在することが私たちの最近の研 究で分かってきました。この状態は，術前矯正においてデンタルコンペンセーションの除去が十分に なされていなかったことを意味します。

この問題に対して私達は, 初診時から仮想患者モデルを生成して術前矯正のための明確なゴール設 定が行えるよう本システムを更新し，これまでの咬合を基準にしたボトムアップ型の外科的矯正治療 から(1)から(3)の骨格系に最適なゴールを設定し，それに(4)から(6)の歯系を調和させるトップダウン型 の外科的矯正治療へ移行する準備を進めています。今回は，その治療のプロトコルを供覧して皆様の ご意見を伺いたいと思います。 


\section{略 歴}

1997 年 北海道医療大学歯学部歯学科 卒業

北海道医療大学歯学部 歯科矯正学講座 卒後研修医

1998 年 北海道医療大学歯学部 歯科矯正学講座 臨床研修生

2000 年 北海道医療大学歯学部附属病院 病院助手

2002 年 日本矯正歯科学会 認定医

2003 年 北海道医療大学歯学部 歯科矯正学講座 助手

2007 年 北海道医療大学歯学部 口腔構造 - 機能発育学系歯科矯正学分野 助教

2008 年 歯学博士取得

2010 年 北海道医療大学歯学部 口腔構造 ・機能発育学系歯科矯正学分野 講師 日本矯正歯科学会 指導医

現在に至る 
$\mathrm{CAD} / \mathrm{CAM}$ により作製したバイトプレートを用いた より正確な上顎顎位の決定方法

Establishment of accurate maxillary position determination using a bite plate which is formed by the $\mathrm{CAD} / \mathrm{CAM}$

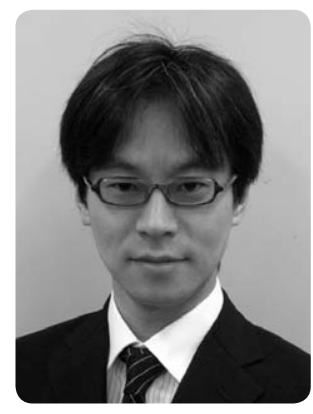

土生学

Manabu Habu

九州歯科大学 生体機能学講座 顎顔面外科学分野

Department of Biological Function,

Division of Maxillofacial Surgery,

Kyushu Dental University

顎変形症手術，特に上下顎骨切り術に扔ける顎位は，cephalometric prediction（CP）を基に決定 されてきた。しかし，CP は二次元的な分析であるため, yawing な゙の修正が必要な場合は, 分析 や設計自体も困難である。また，CPで決定された顎位をフェイスボートランスファーしたス夕 ディーモデルのモデルサージェリーを行って double splint を作製する方法が一般的と思われるが, その間に手技的誤差があることも明らかである。さらに，モデルサージェリーのシミュレーションを 術野に正確に再現する手技は全く確立されて扔らず, reference point を頼りに顎位を決めていると いうのが実情と考える。われわれはそれらを解決する手段の一つとして, 術前の 3D-CT デー夕を基 に顎位を決定し, そのCT データから CAD/CAM でdouble splintを作製し, そのシミュレーション を術野に簡便かつ正確に再現する手法を開発したので報告する。

顎位の決定は, 術前の 3D-CT データをシミュレーションソフト (SimPlant ${ }^{\circledR}$ Crystal) に入力し, CP で得られた骨格の大まかな移動をソフト上で行った上で, 顔貌の軟組織構築画像を基に yawing を含めた細かい微調整を行う方法を用いている。これで決定された上顎の位置を再現するための 1 次 スプリントを術前 CT の DAICOM データおよび上下顎歯列模型の 3D データを用いCAD/CAM で 作製する。手術に際しては術前 CT を撮影した下顎の位置（敢えて咬頭嵌合位を取らせず，術者が規 定した位置でスプリント（0 次スプリント）を咬ませて撮影している）を再現させるため，下顎枝の 位置を三次元的に位置決めする手法（Tominaga et al. IJOMS, 2009）を用いる。すなわち，上顎の骨 切り前に下顎枝と頓骨の間で位置決装置を作製し, 上顎の骨切り後にその装置を再装着し, 1 次久 プリントで上顎の位置決めを行うというものである。これにより two jaw surgeryにおける上顎の位 置決めがより正確にできるようになったことはすでに報告した（Kokuryo et al. OSOMOP, 2014）。

顎変形症治療のゴールは機能と審美の調和である。本法を用いることで顔面非対称などの複雑な変 形を持った症例でも機能と審美の調和のとれた結果を予測しつつ治療計画が立てられ, それが害行で きるようになると考える。講演では実際の症例を提示しつつ，その再現性について報告する。 


\section{略 歴}

1998 年 九州歯科大学 卒業

2002 年 九州歯科大学大学院歯学研究科 修了 (口腔外科学第 1 専攻)

2002 年 佐賀医科大学 (現佐賀大学) 医学部麻酔蘇生科 医員

2003 年 九州歯科大学 助手 (口腔外科学第 1 講座)

2007 年 九州歯科大学 助教 (病態制御学分野)

2013 年 九州歯科大学 病院講師 (顎顔面外科学分野)

2014 年 Visiting Professor, Department of Maxillo-Facial Surgery of San Paolo University Hospital, Milano, Italy

\section{学会等資格}

日本口腔外科学会認定 口腔外科専門医

日本がん治療認定医機構 がん治療認定医（歯科口腔外科） 


\section{当科での外科的矯正治療における下顎位の決定と術後変化 The positioning of mandible and the postoperative changes by orthognathic surgery in our department}

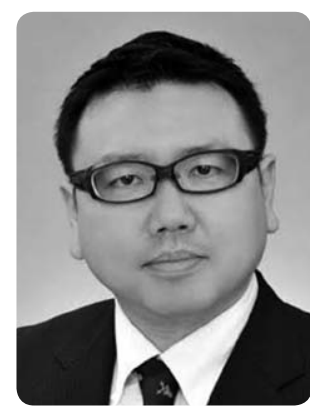

成田 真人

Masato Narita

東京歯科大学 口腔顎顔面外科学講座

Department of Oral \& Maxillo Facial Surgery, Tokyo Dental College

顎矯正手術を行う場合, 術前矯正が適切に行われたうえでの手術が最も好ましいのは多くの外科医 の希望するところではありますが，治療期間や患者の手術希望時期などもあり，必ずしも術前の咬合 が完全な場合に手術を行えるとは限りません。また，昨今では Surgery First や Early Surgery に対 する矯正歯科医の関心も集まってきているのも事実です。しかし，いずれの手術時期においても，私 たち口腔外科医は手術時の下顎頭位の決定，すなわち近位骨片の位置付けを経験と感に頼って行わな ければならず，その適切な目標位置がはっきりとしておらず，あくまで術前の下顎頭の位置を再現す ることが重要と言われているにすぎません。さらに，下顎前突症と下顎後退症とでは，治療中ことに 術中の顎位の変化は大きく異なり, 術中の不用意な位置づけ操作は relapse の原因にもなります。と くに，下顎後退症では下顎頭の変形を伴うことも多く，下顎頭と下顎窩の位置関係が機能的位置から 外れていることが多く, 近位骨片の位置づけが難しいことに加えて, 全身麻酔時の筋弛緩状態が下顎 頭を適切な位置に誘導することをさらに困難としています。

今回は，外科的矯正手術時の顎位の決定方法を下顎前突症と下顎後退症とに分けて，われわれの 行っている手術術式の工夫や手術時の下顎頭位置の決定方法について述べていきたいと思っていま す。当科では, 外科的矯正治療にあたり従来の二次元的な分析として Sassouni 分析, Ricketts 分析 や Ritucci-Burstone 分析などを併用して骨格の対称性，上顎骨・下顎骨の垂直的，水平的な位置を評 価し治療計画を擬似的な三次元として行ってきました。最近では, X 線 CT 画像を用いて, 三次元顎 矯正手術支援ソフトウエア（SimPlant O \& $\mathrm{O}^{\circledR}$; Materialise Dental）での三次元セファロ分析と手術 シミュレーションによる骨片移動による干渉の予測や下顎頭位置の変化予測も含めた治療計画を行っ て，事前の対応を検討しています。

また，実際の骨切りに際しては，手術中に術前シミュレーションの骨切り位置を再現するための工 夫や骨切り方法を検討することで, 骨片に付着した勒帯をコントロール (剥離, 非剥離) することで, 近位骨片の徒手的な復位や後戻りを防ぐ計画で対応しています。さらに，最終的な骨接合の手法を下 顎頭形態と復位状態にあわせて強固な固定から調節式までを適切に選択するといった対応により, 診 断から手術計画（骨切り法）から骨接合までを統合的に考えた顎位の設定を行っています。

さらに，われわれの行っている治療計画における顎位の変化を含め, 術前後の変化について, X 線 CT を用いた三次元的変化についても検討してみましたのでご報告させていただきます。 


\section{略 歴}

2000 年 東京歯科大学 卒業

東京歯科大学 千葉病院 臨床研修医

2001 年 東京歯科大学 口腔外科学第 II 講座 入局

2006 年 東京都立大塚病院 口腔科 医員

2011 年 東京歯科大学 口腔外科 助教

現在に至る

\section{学会等資格・役職}

日本口腔外科学会専門医 


\section{How to decide jaw position and surgical occlusion in surgery-first approach}

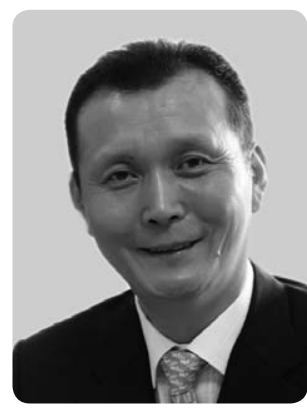

Hee-Kyun $\mathrm{OH}$

Dept. of OMFS, School of Dentistry,

Chonnam National University, Korea

Conventional orthognathic surgery approach requires pre-surgical orthodontic decompensation. However, this approach has several problems including the worsening of pre-surgical facial profile and the long treatment time in most cases. In recent years, the surgery-first approach (SFA) of orthognathic treatment can bring immediate improvement in facial appearance to the better satisfaction of patients. It can also shorten the overall treatment time by having pre-surgical orthodontics eliminated or greatly reduced. However, there are some drawbacks to this approach. In many cases, the upper and lower dental arch cannot be placed in an ideal occlusion due to dental interferences. In most patients of SFA, the mandible moves anterosuperiorly as occlusal interference reduces during the post-surgical orthodontic treatment. And the overbite increases and the anterior facial height decreases. It is difficult to predict the amount of change in vertical dimension and the amount of the anteroposterior movement of teeth after the completion of post-surgical orthodontic treatment. Therefore, precise prediction of vertical and horizontal dimensional changes is important to get a successful result in SFA. The jaw position and surgical occlusion should be decided to compensate these post-surgical dimensional changes. There are some factors that might reduce post-operative skeletal stability due to unstable occlusion in SFA. In this presentation, the considerations in SFA, such as how to decide the jaw positions and surgical occlusion and maintain the post-surgical skeletal stability will be discussed with several cases. 


\section{略 歴}

1985 D.D.S., College of Dentistry, Chonnam National University

1985-1989 Intern, resident, Dept of Oral and Maxillofacial Surgery, Chonnam National University Dental Hospital

1989 Master Degree, Graduate School of Chonnam National University

$1995 \quad$ Ph D Degree, Graduate School of Chonnam National University

1999-2000 Fellowship at the Department of Head and Neck Surgery, MD Anderson Cancer, Houston, Texas, USA

2000-2005 Director of Chonnam National University Dental Hospital

2005-2006 Chairman of Dept. of OMFS, Chonnam National University Hospital

1997-Present Full-time instructor, Assistant Professor, Associate Professor, Professor

2007-2011 Dean of School of Dentistry, Chonnam National University

2011-2014 General secretory, Korean Association of Dental Science

2012-Present Vice president of Korean Association of Maxillofacial Plastic Reconstructive Surgeons

2014-Present Treasurer, Asian Association of Oral and Maxillofacial Surgeons Vice chair of organizing committee of 2017 ICOMS Chair of Scientific committee of 2017 ICOMS 